\title{
Geastrum echinulatum and G. rusticum (Geastraceae, Basidiomycota) - two new records for Central America
}

\author{
Freitas-Neto $\mathrm{JF}^{1,}$ Sousa $\mathrm{JO}^{2}$, Ovrebo $\mathrm{CL}^{3}$ and Baseia $\mathrm{IG}^{1,2}$ \\ ${ }^{1}$ Departamento de Botânica e Zoologia, Universidade Federal do Rio Grande do Norte, Natal, Rio Grande do Norte, \\ 59072-970 Brazil. \\ ${ }^{2}$ Programa de Pós-graduação em Sistemática e Evolução, Universidade Federal do Rio Grande do Norte, Natal, Rio \\ Grande do Norte, 59072-970 Brazil. \\ ${ }^{3}$ Department of Biology, University Central Oklahoma Edmond, Oklahoma, 73034 U.S.A.
}

Freitas-Neto JF, Sousa JO, Ovrebo CL, Baseia IG 2019 - Geastrum echinulatum and G. rusticum (Geastraceae, Basidiomycota) - two new records for Central America. Studies in Fungi 4(1), 14-20, Doi 10.5943/sif/4/1/2

\begin{abstract}
Present work describes two new records of Geastrum species from Central America, Geastrum echinulatum (Costa Rica) and G. rusticum, (Panama). Identification of species confirmed based on the macro- and micro-morphological analyses and the published literature of the two species. Field photographs, macroscopic and microscopic characteristics, taxonomic observations and a map of collection sites are provided.
\end{abstract}

Key words - Biodiversity - Earthstars - Fungi - Geastrales - Taxonomy

\section{Introduction}

Geastrum Pers. is a star-shaped gasteroid genus with worldwide distribution (Zamora et al. 2014). The taxonomic knowledge about this genus from Latin America has increased greatly in recent years (Zamora et al. 2013, Sousa et al. 2014a, 2015, Bautista-Hernández et al. 2015). This region has high potential for discovery of hidden diversity, mainly because the presence of tropical forests where there are possibly millions of unnamed fungal species (Hawksworth 2001). Just in the last decade, about one specie per year has been described from Latin America with most of the them being found from Brazil and just one from Argentina (Baseia \& Calonge 2006, Cabral et al. 2014a, 2014b, 2017, Hernández-Caffot et al. 2016, Crous et al. 2016, 2017, 2018, Fazolino et al. 2008, Silva et al. 2013, Sousa et al. 2015).

Approximately 40 species of the genus Geastrum recorded from Central America, which distributed in five countries viz. Costa Rica, Cuba, Guatemala, Panama and Domincan Republic. Costa Rica showed greatest diversity of them. (Arzú et al. 2012, Calonge et al. 2005, Calonge \& Mata 2004, 2006, Coker \& Couch 1928, Dennis 1970, Gube \& Piepenbring 2009, Guzmán 1986, Hernández et al. 2008, Saccardo 1888). The species richness of Geastrum is still underestimated for tropical and subtropical regions, however in the last years there is an increase in new records for these regions, as example for Brazil, which included about 56 species for the statistics, more species than in Central America (Cabral et al. 2017). In this work we contribute to the knowledge of Geastrum in Central America by reporting on two new species records for the region. 


\section{Materials \& Methods}

\section{Collection site details}

The specimens were collected in two rain forest regions of Central America (Fig. 1): La Selva Research Station, which has an area of $15 \mathrm{~km}^{2}$, located in the Province of Heredia, Costa Rica with the geographic coordinates $-10^{\circ} 25^{\prime} 19^{\prime \prime} \mathrm{N}$ and $-84^{\circ} 00^{\prime} 54^{\prime \prime} \mathrm{W}$; and Barro Colorado Island, which has an area of $15.6 \mathrm{~km}^{2}$, located in the Province of Panama, Gatun Lake, Panama, with geographic coordinates -9 ${ }^{\circ} 11^{\prime} 48.7^{\prime \prime} \mathrm{N}$ and - 7954'19.6" W. Additional details on La Selva Research Station can be found in Ovrebo \& Baroni (1988) and see Buyck \& Ovrebo (2002) for more information about Barro Colorado Island.

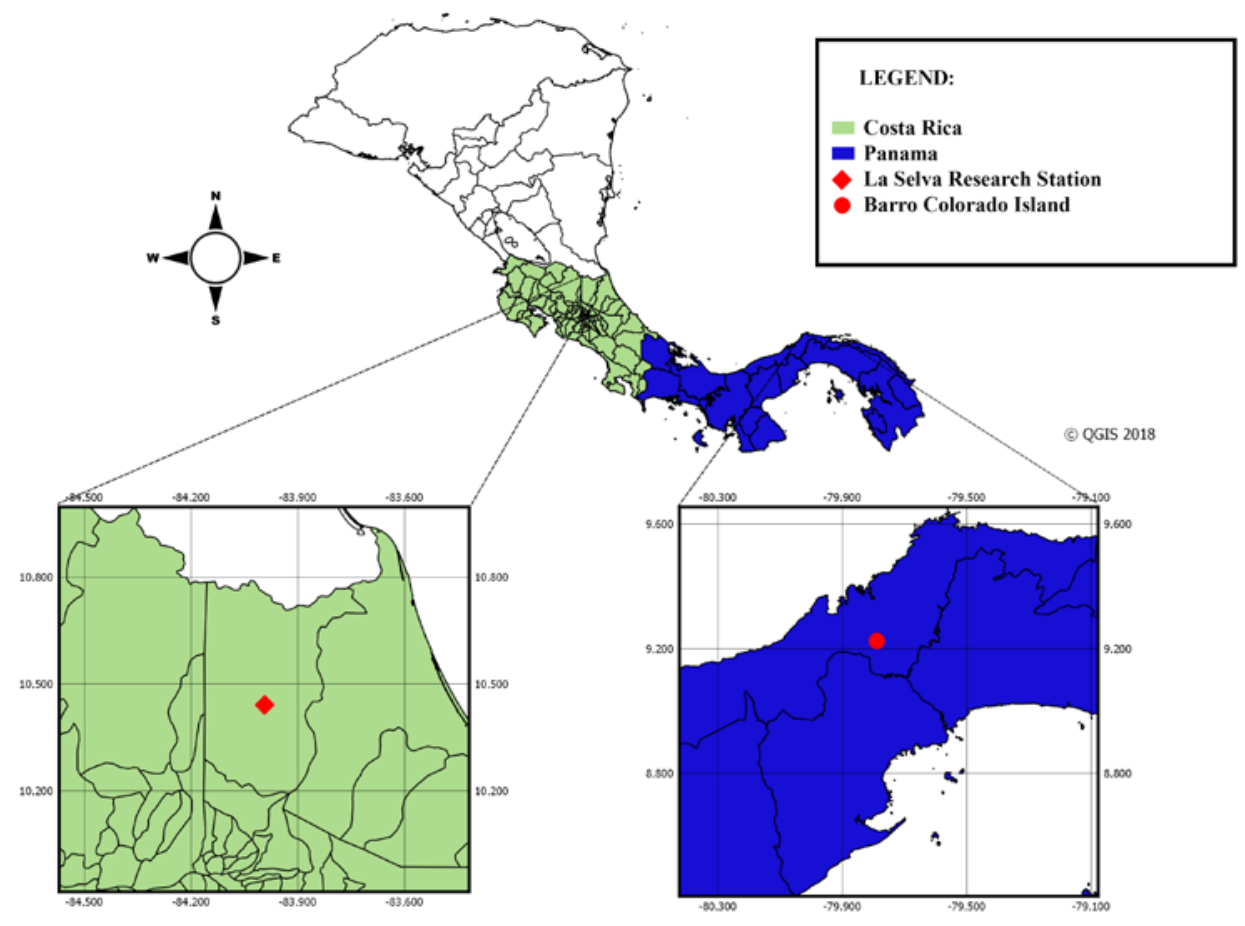

Fig. 1 - Map showing the collection site, La Selva Research Station - Costa Rica and Barro Colorado Island - Panama.

\section{Collection}

The specimens were photographed in situ or repositioned after collection for photographing. The specimens were separately packed and labeled, and data were recorded for location, date, collector, and the specimen habitat: substrate; growth of immature basidiomata (under or above soil); gregarious or caespitose disposition. In the laboratory the samples were dehydrated and stored in plastic zip-lock bags (Silva et al. 2014).

\section{Macro-anatomical analysis}

The morphological analyses were carried in Laboratory of Biology of Fungi (LBF), Department of Botany and Zoology (DBZ) - Federal University of Rio Grande do Norte (UFRN) following the methods of Sunhede (1989), Silva et al. (2014), Sousa et al. (2014c). The macroscopic analysis consisted of detailed observations with the naked eye and with the aid of the Nikon SMZ1500 stereomicroscope attached with a Nikon DS-Ri1 camera, color comparisons were made using Kornerup \& Wanscher (1978). For observation of basidiomata the microstructures will be drawn freehand, small portions of this material, with stereomicroscope and the aid of two histological clamps the layers are separated and placed on separate slides containing the aqueous solution of potassium hydroxide $5 \%(\mathrm{KOH})$. Then the hyphae will be separated with the tweezers, sometimes with the help of insulin syringes $(1 \mathrm{ml})$ with needle $13 \mathrm{~mm} \times 0.3 \mathrm{~mm}$, until the contents 
become almost homogeneous and finally observed under the Nikon Eclipse Ni (LM) microscope with a Nikon camera DS-Ri1 coupled, usually using objective ones with increase of 40 or 100 times (Silva et al. 2014). To obtain the microscopic data, at least 30 basidiospores were measured (including the ornaments), and 20 measurements of each one of the other microstructures, both of them randomically selected. Statistical measurements were calculated using the mean of basidiospore diameter and height, standard deviation ( $\mathrm{x} \pm \mathrm{SD}$, respectively), as well as the quotient between width and mean height (Qm) (Sousa et al. 2017). All measurements were performed using the software NIS - Elements AR v.4.51.00.

\section{Results}

\section{Taxonomy}

Geastrum echinulatum T.S. Cabral, B.D.B. Silva \& Baseia, Nova Hedwigia 96(3-4): 450 (2013)

Facesoffungi Number: FoF 05795

Unexpanded basidiomata epigeous, 10-24 × 7-21 mm, brown yellowish (5D5), subglobose to pyriform, surface not encrusted, echinulate, covered by triangular processes (0.7-1.0 mm high). Subiculum above basidiomata base, white (4A1). Expanded basidiomata saccate, 18-25 mm high (including peristome) $\times$ 40-42 mm wide. Exoperidium splitting into 7 triangular rays, revolute, non-hygroscopic. Mycelial layer brown yellowish (5D5), not encrusted with debris, echinulate to velutinous with age, persistent or peeling-off from the basidioma base. Fibrous layer white (4A1), papery. Pseudoparenchymatous layer dark brown (6F4), persistent or peeling-off in irregular patches, especially on the base of rays. Endoperidial 13-11 $\times 21 \mathrm{~mm}$, depressed globose, greyish brown (6D3), sessile, surface glabrous. Apophysis absent. Peristome fibrillose, non-delimited, conical, concolorous endoperidium, $<1 \mathrm{~mm}$ high. Gleba dark brown (7F4). Basidiospores 4.3-5.1 $\times 4.0-5.0 \mu \mathrm{m}\left[x=4.7 \pm 0.2 \times 4.6 \pm 0.2, \mathrm{Q}_{\mathrm{m}}=1.03, \mathrm{n}=30\right]$, globose to subglobose, brownish, ornamentations verrucous, warts $0.7-1.0 \mu \mathrm{m}$ high. Basidia 10.6-25.7 $\times 3.9-7.6 \mu \mathrm{m}$ clavate, thinwalled $(0.3-1.0 \mu \mathrm{m})$, yellowish, 3-5 sterigmata. Eucapillitium 3.6-6.1 $\mu \mathrm{m}$ diam., yellowish, thinwalled $(0.6-1.1 \mu \mathrm{m})$, surface encrusted, lumen inconspicuous. Mycelial layer composed of thinwalled $(0.5-0.7 \mu \mathrm{m})$ hyphae, 5.5-16.6 $\mu \mathrm{m}$ diam., yellowish, surface non-encrusted, non-branched and lumen evident. Fibrous layer composed of hyaline, thin-walled (0.3-0.6 $\mu \mathrm{m})$ hyphae, 3.6-5.6 $\mu \mathrm{m}$ diam., surface non-encrusted, non-branched and lumen evident. Pseudoparenchymatous layer composed of thick-walled $(0.6-1.1 \mu \mathrm{m})$ hyphal cells, subglobose, oval to elongated, 37.2-82.5 $\times$ 22.9-59.8 $\mu \mathrm{m}$.

Known distribution - BRAZIL- Amazonas and Bahia (Silva et al. 2013).

Material examined - Costa Rica, Province of Heredia, La Selva Research Station, on wood, 12 Jun 1986, -10²5'19" N, -8400' 54", Ovrebo C.L., Ovrebo 2224 (UFRN-Fungos 3000).

Geastrum rusticum Baseia, B.D.B. Silva \& T.S. Cabral, Nova Hedwigia 98(1-2): 265 (2014)

Facesoffungi Number: FoF 05796

Fig. 3

Unexpanded basidiomata absent. Expanded basidiomata saccate, 14-18 mm high (including peristome) $\times$ 32-38 mm wide. Exoperidium splitting into 5-6 triangular rays, revolute, nonhygroscopic. Mycelial layer double layered, outer layer orange white (5A1), surface cotonous, encrusted with debris, inner layer gray orange (5B2), papery. Fibrous layer yellowish white (4A2), coriaceous. Pseudoparenchymatous layer yellowish brown (5E6; 5D6), rimose, persistent to peeling-off in irregular patches. Endoperidial greyish brown (6D3; 6E3), depressed globose, 13-14 $\times 18-20 \mathrm{~mm}$, sessile, surface glabrous. Apophysis absent. Peristome fimbriate, non-delimited, conical to flat, darker than endoperidium, $<1 \mathrm{~mm}$ high. Gleba greyish brown (6F3). Basidiospores $4.8-5.9 \times 4.8-5.9 \mu \mathrm{m}\left[x=5.4 \pm 0.3 \times 5.2 \pm 0.3, \mathrm{Q}_{\mathrm{m}}=1.02, \mathrm{n}=30\right]$, globose to subglobose, brownish, ornamentation verrucose, warts $0.7-1.5 \mu \mathrm{m}$ high. Eucapillitium 4.2-8.0 $\mu \mathrm{m}$ diam., thin- 
walled (0.6-1.3 $\mu \mathrm{m})$, light brown; surface encrusted, lumen evident. Mycelial layer composed of hyaline, thin-walled $(0.2-0.4 \mu \mathrm{m})$ hyphae, 1.8-3.2 $\mu \mathrm{m}$ diam., surface non-encrusted, non-branched and lumen evident. Fibrous layer composed of hyaline, thin-walled $(0.4-0.7 \mu \mathrm{m})$ hyphae, 3.9-10.5 $\mu \mathrm{m}$ diam., surface non-encrusted, non-branched and lumen evident. Pseudoparenchymatous layer composed of brownish, thin-walled $(0.5-0.8 \mu \mathrm{m})$ hyphal cells, subglobose, oval to elongated, 19.1$54.3 \times 11.7-49.9 \mu \mathrm{m}$.

Known distribution - BRAZIL - Rio Grande do Norte (Cabral et al. 2014b), Ceará e Paraíba (Sousa et al. 2014b).

Material examined - Panama, Province of Panama, Gatun Lake, Barro of Colorado Island, on leaf-litter, 12 Jul 1997, -9¹1'48.7" N, -7954'19.6" W, Ovrebo C.L., Ovrebo 3620 (UFRN-Fungos 3003).

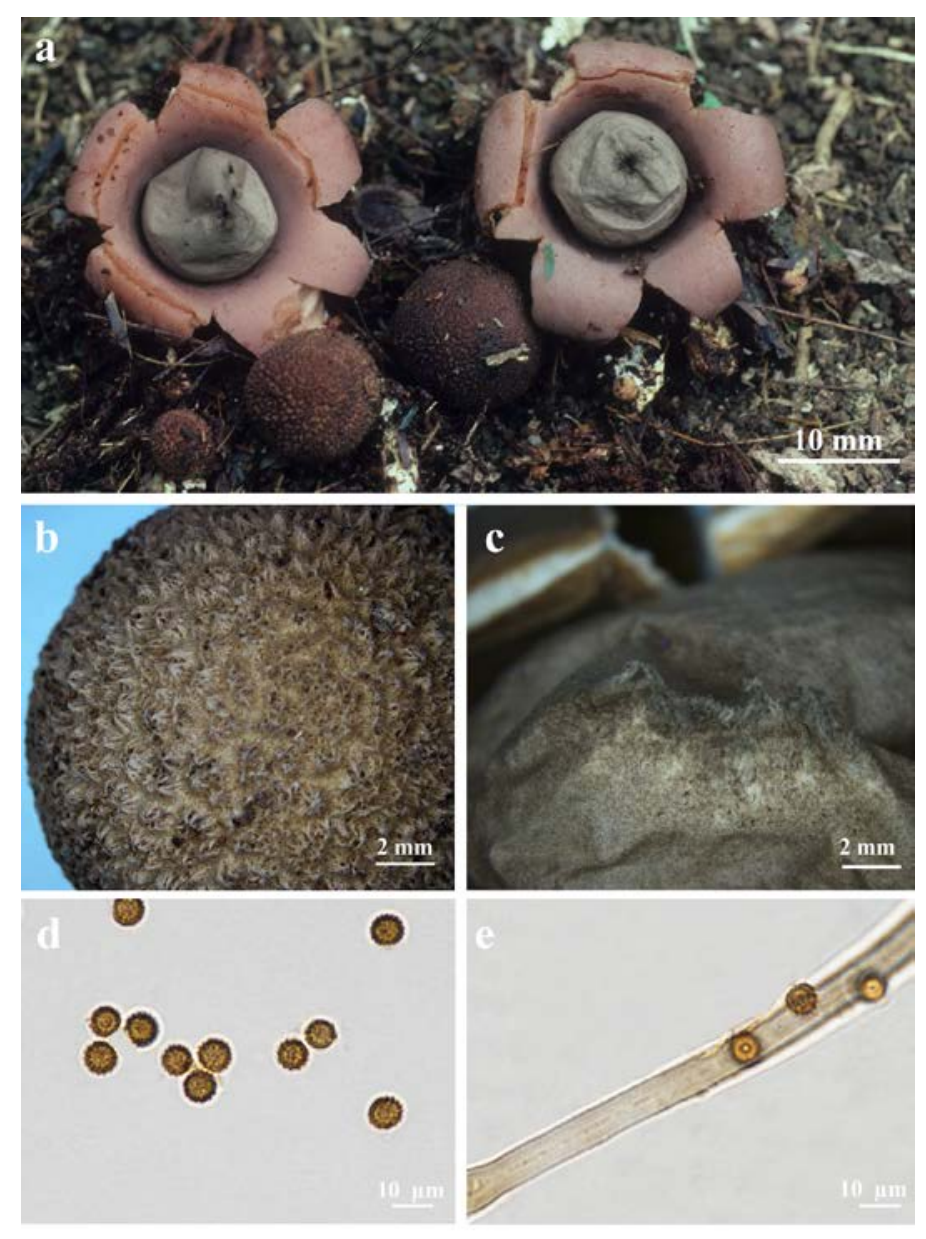

Fig. 2 - Geastrum echinulatum (UFRN-Fungos 3000). a Basidiomata in situ. b Echinulate mycelial layer. c Peristome. d Basidiospores. e Eucapillitium.

\section{Discussion}

Geastrum echinulatum is mainly recognized by it echinulate exoperidium, covered by triangular processes, presence of subiculum, fibrillose and non-delimited peristome (Silva et al. 2013). The morphology of this species fits well in section Exoareolata (Zamora et al. 2014). Geastrum litchiforme Desjardin \& Hemmes and Geastrum aculeatum B.D.B Silva \& Baseia are closely related to $G$. echinulatum, both have saccate basidiomata, fibrillose and non-delimited peristome and exoperidium with prominent tuffs. Geastrum litchiforme differs by the presence of an ephemeral mycelial layer, smaller basidiospores $(3.2-3.8 \mu \mathrm{m})$ and absence of subiculum (Hemmes \& Desjardin 2011). Geastum aculeatum is distinguished by the characters like color of pseudoparenchymatous layer (violet gray to blueish gray) and larger basidiospores (5.0-7.5 um) (Silva et al. 2013). Our analyzes compared with the description of the species type of $G$. 
echinulatam corroborate the protologue. Until now, G. echinulatum have distribution restrict to Brazilian territory and this is the first record to Central America.

Geastrum rusticum is characterized by its semi-hypogeous immature basidiomata, lacerated and non-delimited peristome, mycelial layer incrusted with sand debris and incospicuos basidiospores ornamentation. This species resembles with Geastrum fimbriatum Fr. which is distinguished by the absence of endoperidium stalked with protruding hyphae, basidiospores ornamentations up to $1.1 \mu \mathrm{m}$ high (Sousa et al. 2014c, Trierveiler-Pereira et al. 2011). Other similar species included Geastrum ishikawae Accioly, JO Sousa, Baseia \& MP Martín and Geastrum hieronymi Henn, all three species have a cotonous mycelial layer incrusted with sand debris and non-delimited fibrillose peristome. Geastrum rusticum is distinguished from the former species by the lack of a pruinose endoperidium with protruding hyphae and the peristome is flattened to folded (Crous etal. 2016); Geastrum hieronymi differs by the lack of endoperidium stalked with protuberant hyphae and it has verrucose basidiospores (Leite et al. 2007). Geastrum rusticum can also be compared to Geastrum morganii Lloyd. both species have a light endoperidium, saccate basidioma and absence of stalk. However, G. morganii is distinct to G. Rusticum by the presence of an irregularly sulcate peristome, lacks incrustations in the mycelial layer and, in some cases, may present a collar in the pseudoparenquematous layer. Our analyzes when compared to the description of the type species of G. rusticum corroborate with the protologue, except for the ornamentations that are conspicuous in the basidiospores $(0.7-1.5 \mu \mathrm{m})$. Until now, G. rusticum was known only from Northeast Brazil (Ceará, Paraíba and Rio Grande do Norte States) and this is the first record for Central America.
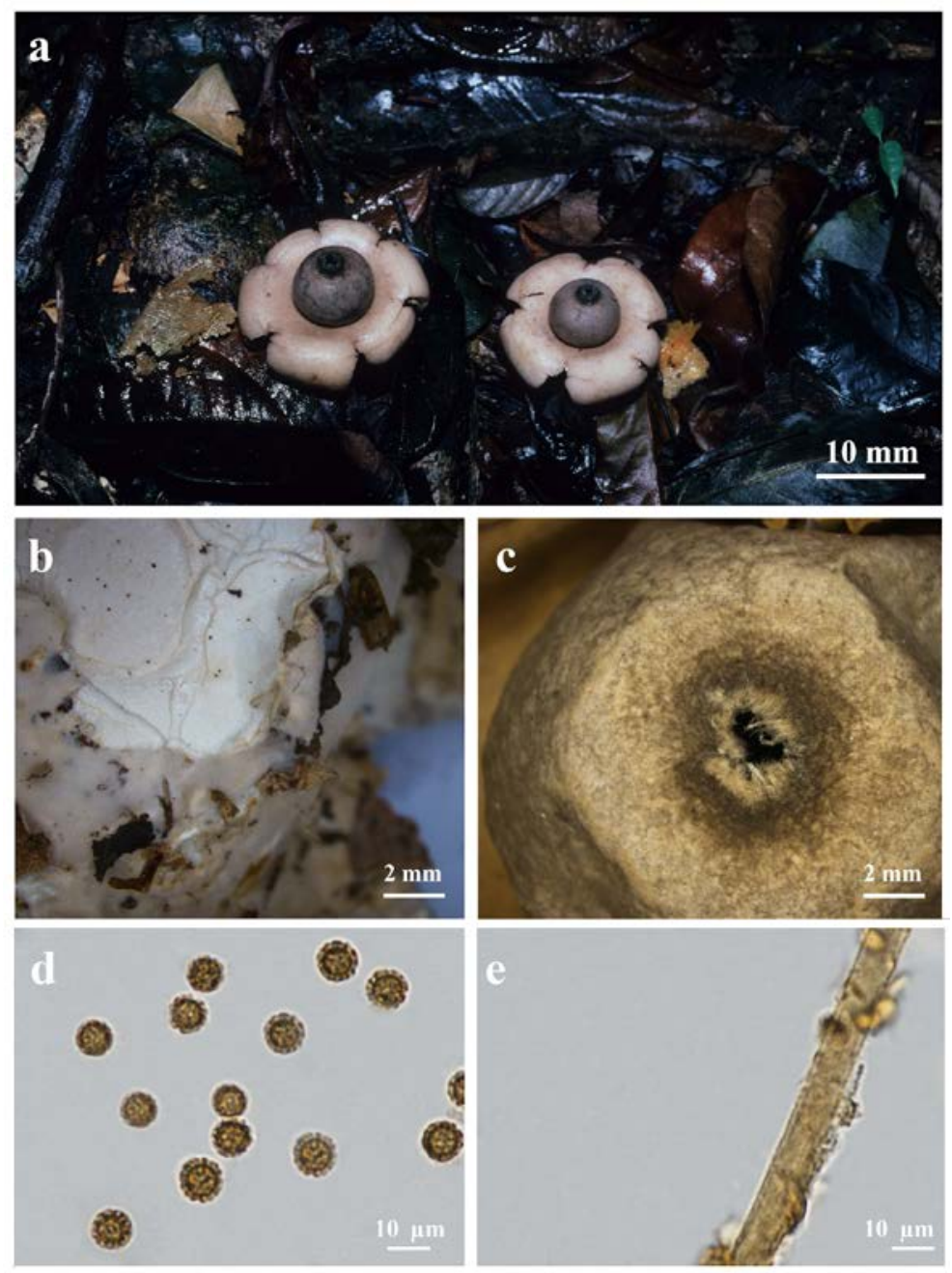

Fig. 3 - Geastrum rusticum (UFRN-Fungos 3003). a Basidiomata in situ. b Mycelial layer. c Peristome. d Basidiospores. e Eucapillitium. 


\section{Acknowledgements}

The authors thank the Coordenação de Aperfeiçoamento de Pessoal de Nível Superior (CAPES-Brazil) and to the Conselho Nacional de Desenvolvimento Científico e Tecnológico (CNPq-Brazil) for the scholarships awarded to Julieth de Oliveira Sousa and Julimar Freitas-Neto respectively. C. L. Ovrebo thanks the Organization for Tropical Studies for granting permission to collect at La Selva Research Station and thanks the Smithsonian Tropical Research Institute for permission to collect on Barro Colorado Island.

\section{References}

Arzú R, Comandini O, Rinaldi AC. 2012 - A Preliminary checklist of macrofungi of Guatemala, with notes on edibility and traditional knowledge. Mycosphere 13, 1-21.

Baseia IG, Calonge FD. 2006 - Geastrum hirsutum: a new earthstar fungus with a hairy exoperidium. Mycotaxon 95, 301-304.

Bautista-Hernández S, Acosta EG, Raymundo T, Herrera T et al. 2015 - Geastrum violaceum, registro nuevo para México. Revista Mexicana de Biodiversidad 86(3), 569-572.

Buyck B, Ovrebo CL. 2002 - New and interesting Russula species from Panama. Mycologia 94(5), 888-901.

Cabral TS, Silva BDB, Ishikawa NK, Alfredo DS et al. 2014a - A new species and new records of gasteroid fungi (Basidiomycota) from Central Amazonia, Brasil. Phytotaxa 183(4), 239-253.

Cabral TS, Silva BDB, Marinho P, Baseia IG. 2014b - Geastrum rusticum (Geastraceae, Basidiomycota), a new earthstar fungus in the Brazilian Atlantic rainforest - a molecular analysis. Nova Hedwigia 98(1-2), 265-272.

Cabral TS, Sousa JO, Silva BDB, Martín MP et al. 2017 - A remarkable new species of Geastrum with an elongated branched stipe. Mycoscience 58, 344-350

Calonge FD, Mata M. 2004 - A new species of Geastrum from Costa Rica and Mexico. Boletin de la Sociedad Micologica de Madrid 28, 331-335.

Calonge FD, Mata M. 2006 - Adiciones y correcciones al catálogo de Gasteromycetes de Costa Rica. Boletin de la Sociedad Micologica de Madrid 30, 11-119.

Calonge FD, Mata M, Carranza J. 2005 - Contribución al catálago de los Geasteromycetes (Basidiomycotina, Fungi) de Costa Rica. Anales del Jardín Botánico de Madrid 62(1), 23-45.

Coker WC, Couch JN. 1928 - The Gasteromycetes of the Eastern United States and Canada. MBLWHOI Library.

Crous PW, Wingfield MJ, Burgess TI, Hardy et al. 2016 - Fungal Planet description sheets: 469557. Persoonia 37, 218-403.

Crous PW, Wingfield MJ, Burgess TI, Carnegie AJ et al. 2017 - Fungal Planet description sheets: 625-715. Persoonia 39, 270-467.

Crous PW, Wingfield MJ, Burgess TI, Hardy et al. 2018 - Fungal Planet description sheets: 716784. Persoonia 40, 240-393.

Dennis RWG. 1970 - Fungus flora of Venezuela and adjacent countries. England: Kew Bull. Add. Ser, 1-515.

Fazolino EP, Calonge FD, Baseia IG. 2008 - Geastrum entomophilum, a new earthstar with an unusual spore dispersal strategy. Mycotaxon 104, 449-453.

Gube M, Piepenbring M. 2009 - Preliminary annotated checklist of Gasteromycetes in Panama. Nova Hedwigia 89(3-4), 519-543.

Guzmán G. 1986 - Distribuicion de los Hongos em La Region Del Caribe Y Zonas Vecinas. Caldasia 15, 103-120.

Hawksworth DL. 2001 - The magnitude of fungal diversity: the 1.5 million species estimate revised. Mycological Research 105(12), 1422-1432.

Hemmes DE, Desjardin DE. 2011 - Earthstars (Geastrum, Myriostoma) of the Hawaiian Islands including two new species, Geastrum litchiforme and Geastrum reticulatum. Pacific Science 65, 477-496. 
Hernández-Caffot ML, Amarilla LD, Crespo EM, Domínguez LS. 2016 - Geastrum minutisporum sp. nov. from Polylepis Australis woodlands in central Argentina. Mycoscience 57, 157-163.

Hernández MC, González SGMG, Suárez lc. 2008 - Hongos del Jardín Botánico Nacional de Cuba. I. Basidiomycota. Revista del Jardín Botánico Nacional 29, 161-169.

Kornerup A, Wansher JE. 1978 - Methuen handbook of Colour 3.ed.

Leite AG, Calonge FD, Baseia IG. 2007 - Additional studies on Geastrum from Northeastern Brazil. Mycotaxon 101, 103-111.

Ovrebo CL, Baroni TJ. 1988 - Three new species of Rhodocybe from Costa Rica. Mycologia 80(4), 508-514.

Saccardo PA. 1888 - Sylloge Fungorum 7, Ann Arbor: V.W. Edwards (reprinted, 1944), 882.

Silva BDB, Cabral TS, Marinho P, Ishikawa NK, Baseia IG. 2013 - Two new species of Geastrum (Basidiomycota) found in Brazil. Nova Hedwigia 96(3-4), 445-456.

Silva BDB, Sulzbacher MA, Baseia IG. 2014 - Metodologia In: Baseia IG, Silva BDB, Cruz RHSF - Fungos Gasteroides no Semiárido do Nordeste Brasileiro. Feira de Santana: Print Mídia 1, 26-28.

Sousa JO, Morais LA, Nascimento YM, Baseia IG. 2014a - Updates on the geographic distribution of three Geastrum species from Brazilian semi-arid region. Mycosphere 3, 467-474.

Sousa JO, Silva BDB, Alfredo DS, Baseia IG. 2014b - New records of Geastraceae (Basidiomycota: Phallomycetidae) from Atlantic Rainforest Remmants and Relicts of Northeastern Brazil. Darwiniana Nueva Serie 2(2), 207-221.

Sousa JO, Silva BDB, Baseia IG. 2014c - Geastrum from the Atlantic Forest in northeast Brazil new records for Brazil. Mycotaxon 129, 169-179.

Sousa JO, Baracho GS, Baseia IG. 2015 - Geastrum laevisporum: a new earthstar fungus with uncommon smooth spores. Mycosphere 6(4), 501-507.

Sousa JO, Suz LM, García MA, Alfredo DS et al. 2017 - More than one fungus in the pepper pot: Integrative taxonomy unmasks hidden species within Myriostoma coliforme (Geastraceae, Basidiomycota). Plos One 12(6), 1-19.

Sunhede S. 1989 - Geastraceae (Basidiomycotina). Morphology, ecology and systematics with special emphasis on the North European species. Synopsis Fungorum 1, 1-534.

Trierveiler-Pereira L, Calonge FD, Baseia IG. 2011 - New distributional data on Geastrum (Geastraceae, Basidiomycota) from Brazil. Acta Botânica Brasílica 25(3), 577-585.

Zamora JC, Calonge JC, Martín MP. 2013 - New sources of taxonomic information for earthstars (Geastrum, Geastraceae, Basidiomycota): phenoloxidases and rhizomorph crystals. Phytotaxa 131(1), 1-10.

Zamora JC, Calonge FD, Hosaka K, Martín MP. 2014 - Systematics of the genus Geastrum (Fungi: Basidiomycota) revisited. Systematics and Phylogeny. Taxon 63(3), 447-497. 